\title{
Psychological morbidity, quality of life, and self-rated health in the military personnel
}

\author{
This article was published in the following Dove Press journal: \\ Neuropsychiatric Disease and Treatment \\ 17 February 2014 \\ Number of times this article has been viewed
}

\author{
Han-Wei Chou ${ }^{1-3}$ \\ Wen-Chii Tzeng ${ }^{4,5}$ \\ Yu-Ching Chou ${ }^{6}$ \\ Hui-Wen Yeh ${ }^{4,7}$ \\ Hsin-An Chang ${ }^{1,5}$ \\ Yu-Cheng Kao ${ }^{1,8}$ \\ Nian-Sheng Tzeng 1,5 \\ 'Department of Psychiatry, Tri- \\ Service General Hospital, School of \\ Medicine, ${ }^{2}$ Department of Psychiatry, \\ Tri-Service General Hospital, Beitou \\ Branch, National Defense Medical \\ Center, Taipei, Taiwan; ${ }^{3}$ Department of \\ Psychiatry, Tao-Yuan General Hospital, \\ Tao-Yuan, Taiwan; ${ }^{4}$ Department \\ of Nursing, Tri-Service General \\ Hospital, School of Nursing, ${ }^{5}$ Student \\ Counseling Center, ${ }^{6}$ School of Public \\ Health, National Defense Medical \\ Center, Taipei, Taiwan; ${ }^{7}$ Department \\ of Nursing, School of Nursing, Kang- \\ Ning Health Care and Management \\ College, Taipei, Taiwan; ${ }^{8}$ Department \\ of Psychiatry, Tri-Service General \\ Hospital, Song-Shan Branch, National \\ Defense Medical Center, Taipei, Taiwan
}

Correspondence: Nian-Sheng Tzeng Division of Community Psychiatry, Department of Psychiatry, Tri-Service General Hospital, 325, Sec 2,

Chenggong Road, Neihu District,

Taipei City I I4, Taiwan

Tel +886287927 299

Fax +886287927221

Email pierrens@mail.ndmctsgh.edu.tw
Objective: The mental health of military personnel varies as a result of different cultural, political, and administrative factors. The purpose of this study was to evaluate the psychological morbidity and quality of life of military personnel in Taiwan.

Materials and methods: This cross-sectional study utilized the World Health Organization Quality of Life Instrument, brief version, Taiwan version, the General Health Questionnaire-12, Chinese version, and the Visual Analog Scale (VAS) in several military units.

Results: More than half of the subjects (55.3\%) identified themselves as mentally unhealthy on the General Health Questionnaire-12, Chinese version; however, a higher percentage of officers perceived themselves as healthy (57.4\%) than did noncommissioned officers (38.5\%) or enlisted men (42.2\%). Officers also had higher total quality of life (QOL) scores (83.98) than did enlisted men (79.67). Scores on the VAS also varied: officers: 72.5; noncommissioned officers: 67.7; and enlisted men: 66.3. The VAS and QOL were positively correlated with perceived mental health among these military personnel.

Conclusion: Our subjects had higher rates of perceiving themselves as mentally unhealthy compared to the general population. Those of higher rank perceived themselves as having better mental health and QOL. Improving mental health could result in a better QOL in the military. The VAS may be a useful tool for the rapid screening of self-reported mental health, which may be suitable in cases of stressful missions, such as in disaster rescue; however, more studies are needed to determine the optimal cut-off point of this measurement tool.

Keywords: military, quality of life, general health scale, Taiwan

\section{Introduction}

Military personnel face multiple stressors in their lives. ${ }^{1,2}$ Studies have reported that stress occurs from risky assignments or missions, ${ }^{3-5}$ the demand for physical fitness, problems in interactions with peers and those of higher rank, ${ }^{6}$ sleep deprivation from shift work, ${ }^{7,8}$ deployment and separation from family, ${ }^{9}$ and additional noncombat work assignments such as disaster relief, peacekeeping, and other humanitarian actions. ${ }^{10}$ Home-front problems with spouses and children also have an impact on the lives of military personnel. ${ }^{9,11,12}$ Global defense budget cuts and the downsizing of military manpower increase the workload and stress of the few remaining military personnel. ${ }^{13-15}$

The World Health Organization's (WHO) definition of health includes physical, mental and social aspects. ${ }^{16}$ Quality of life (QOL) in the context of individual cultural and subcultural systems is associated with personal goals, expectations, standards and values. ${ }^{17}$ The WHO has advocated for the goals of promotion of quality of life, preservation of function and well-being as well as prolongation of peoples' lives. ${ }^{18}$ 
The WHO Quality of Life Instrument (WHOQOL) and its brief version (WHOQOL-BREF) are commonly used scales for use among general populations, as well as among diseasespecific populations. ${ }^{19}$

The mental and physical health of military personnel may vary as a result of different administrative, characteristic, and political factors. ${ }^{20}$ The identification of stressors in military life, as well as the factors that influence health, would enable us to provide proper care for military personnel. Therefore, the relationship between quality of life (QOL) and perceived health are crucial for the maintenance of the welfare of military personnel and troop strength. The aim of this study was to evaluate military personnel from select branches of ground forces in Taiwan for their perceived health status and QOL.

\section{Materials and methods}

\section{Subjects and clinical assessments}

This was a cross-sectional study. Data were collected from basic military units and the Taiwan ground forces units within 1 consecutive year through army, air force, and gendarmeries. There were no differences in ethnicity in this study; all of the participants were Han Chinese in Taiwan.

The researchers contacted each military unit and explained the study to the participants. Inclusion criteria were: 1) membership in one of the military service branches in Taiwan, including mandatory and voluntary entry; 2) the ability to read and write; and 3) agreement that participants' personal information and test results could be used in this research. Personal characteristics of the participants included age, sex, rank, level of education, income, marital status, military service, and mandatory or voluntary enrollment. The packet also included the WHOQOL-BREF, Taiwan version, and the General Health Questionnaire-12 (Chinese version) (CHQ)-12. 16,24 Smoking, alcohol consumption, personal medical conditions, and medical history were also recorded.

Our research team sent out 1,200 questionnaires, of which 900 were returned and, of these, 720 could be used; this led to an effective response rate of $60 \%$.

\section{Instruments}

\section{General Health Questionnaire- I2,}

Chinese version (CHQ)- 12

The CHQ-12 was based on Goldberg's General Health Questionnaire (GHQ) and translated by Cheng. ${ }^{16,21}$ The CHQ-12 reduced the number of questions from 60 to 12 , and it has been used as a screening instrument for anxiety, depression, insomnia, fatigue, social functioning, and family relationships.

The CHQ-12 is a self-reported screening tool. Each question has four possible responses ranging from 0 (not at all), to 3 points (felt much more frequently than usual). Previous research revealed that the CHQ-12 had fair validity and reliability. ${ }^{16,21-23}$ For intrinsic validity, Cronbach's alpha coefficient was 0.9 in a community sample and 0.92 in hospital patients; sensitivities were $76 \%$ and $77 \%$, respectively.

\section{World Health Organization Quality of Life Instrument-BREF, Taiwan version}

The WHOQOL-BREF, Taiwan version was translated by Yao et al, ${ }^{24}$ and it was determined to be both reliable and valid. ${ }^{24,25}$ The Taiwan version added two questions about local culture in addition to the basic 26 questions. This instrument can be used to assess a subject's psychological, physical, social, and environmental conditions over the previous 4 weeks. ${ }^{25}$ Internal consistency ranged from $0.70-0.77$ for the four domains (physical, psychological, social, and environmental), and the test-retest reliability reached $0.76-0.80$ at the domain level. The discriminant validity effectively distinguished healthy from unhealthy people and accounted for $60 \%$ of the total QOL. ${ }^{24}$

\section{Visual Analog Scale (VAS)}

The packet contained part of a self-reported VAS of mental health. The VAS method is widely used to assess the status of a patient's pain or illness. ${ }^{26,27}$ It is a cost-effective way to evaluate a patient's health. ${ }^{28,29}$ The scores range from 0 (the worst) to 100 (the best), and they indicate subjective health over the previous 2 weeks and before the participants entered military service.

\section{Statistical analysis}

SPSS for Windows version 21.0 (IBM Corporation, Armonk, NY, USA) was used for the statistical analysis. Descriptive results of continuous variables were expressed as mean \pm standard deviation, and categorical variables were expressed as frequency (\%). Group differences were determined by Pearson's chi-square $\left(\chi^{2}\right)$ and one-way analysis of variance. One-way analysis of variance was also used to analyze the differences in CHQ and QOL between different ranks, levels of education, groups of mandatory or voluntary military services. Logistic regression was used to estimate odds ratios (ORs) and 95\% confidence intervals for the association between the demographic factors, four WHOQOL-BREF 
domain scores, and psychological morbidity. Multiple regression analysis was used to identify significant variables associated with CHQ, QOL, and VAS of subjective health condition in the past 2 weeks. All statistical tests were twotailed, and values of $P<0.05$ were considered statistically significant.

\section{Ethical statement}

The protocol for this study conformed to the Declaration of Helsinki. Permission for the study was obtained from the institutional review boards of the Tri-Service General Hospital and the National Defense Medical Center.

\section{Results}

We collected 720 useable questionnaires from service members in the army $(n=297 ; 41.3 \%)$, air force $(n=59 ; 8.2 \%)$, gendarme $(n=197 ; 27.4 \%)$, and other participants $(n=167$; $23.1 \%$ ). We divided the collected data into three groups according to the subjects' military rank: officers $(n=162$; $31.3 \%$ ); noncommissioned officers (NCOs) ( $n=104 ; 20.1 \%$ ); and enlisted men $(n=251 ; 48.5 \%)$. None of the enlisted subjects were female, and both the officer $(146 / 14 ; 91.3 \%)$ and the $\operatorname{NCO}(97 / 7 ; 93.3 \%)$ groups were predominantly male. The average age of the officers was 30 years, and they were older than the participants in the NCO (25.3 years) and enlisted groups (23.7 years). The officer group had a higher level of education (15.2 years versus 14.3 years for NCOs and 14.1 years for enlisted men).

Most of the officers were volunteers (138/145; 95.4\%), as were about half the NCOs $(50 / 104 ; 49 \%)$, but very few of the enlisted men were volunteers $(13 / 215 ; 5.7 \%)$, though they were fulfilling their obligatory military duty. Officers had the longest time in service (11.1 years) compared to NCOs (4.8 years) and enlisted men (1.5 years). The enlisted men have lower average incomes than the NCOs and officers. The average monthly income of officers, NCOs, and enlisted men were New Taiwan Dollars (NTD) 28,700 (US \$956.70), NTD 25,600 (US \$853.30), and NTD 16,100 (US \$536.70), respectively.

There were no significant differences in smoking or drinking alcohol in the three groups, as $34.8 \%$ of the officers had a history of smoking and $8.2 \%$ drank alcohol more than once per week. The percentages of a history of smoking and drinking alcohol for NCOs and enlisted men were $37.9 \% / 13 \%$, and $35 \% / 10.5 \%$, respectively.

There were 104 participants who reported that they had ongoing medical problems, including allergies $(n=24)$, skin rash or itching $(n=26)$, common cold symptoms $(n=18)$, musculoskeletal discomfort (strain or sprain: $n=55$; selfreported herniated intervertebral disc: $n=6$; muscle pain: $n=12)$, hepatitis $B$ virus carrier $(n=3)$, peptic ulcer $(n=1)$, hypertension $(n=2)$, and type 2 diabetes mellitus $(n=1)$. The distribution of illness symptoms was not influenced by rank.

The officers had a higher score on the VAS of self-reported health (72.5) than did the NCOs (67.7) or enlisted men (66.3) $(P<0.001)$, but only for the previous 2 weeks. The VAS score for self-reported health before they entered military service showed no significant differences in the three groups (officers: 74.6; NCOs: 71.0; enlisted men: 72.0). The NCOs and enlisted men felt their health had significantly worsened in recent times when compared to the time that passed before they became enlisted (the average number of years enlisted for officers, NCOs, and enlisted men were 11.1 1 7.3 years, 4.8 \pm 5.7 years, and 1.5 \pm 2.4 years, respectively).

As shown in Table 1, officers had lower CHQ scores (9.62) than did NCOs (11.07) and enlisted men (11.51). When we used a score of 9 as the cut-off point (set as the three-quarter cut-off point), ${ }^{22}$ and considered subjects reporting 10 or more points as unhealthy CHQ cases or as cases where there was psychological morbidity, the officers had a higher percentage of good health $(57.4 \%)$ than did the NCOs $(38.5 \%)$ or enlisted men (42.2\%).

The officers also had higher total QOL scores (83.98) than did NCOs (80.64) or enlisted men (79.67). When comparing the four domains of the QOL, officers still had significantly higher scores in each domain than did the enlisted men. NCOs had significantly lower scores than officers in the physical and environmental domains (Table 1 and Figure 1). The QOL showed borderline differences in the different income statuses, but income had no significant influence after adjusting by regression.

Items $1,3,4,5$, and 9 on the CHQ showed significant differences among the three groups. On item 1 (headache) and item 5 (poor sleep quality), NCOs' scores of 2.06 and 2.52, respectively, were higher than those of officers' scores of 1.72 and 2.04, respectively. On item 4 (limb tremor or numbness) and item 5 (poor sleep quality), the enlisted men's scores of 1.62 and 2.48, respectively, were higher than those of officers' scores of 1.43 and 2.04, respectively. (Table 2).

At the cutoff point of a CHQ score of 9, officers felt that they had better health ( $\beta$-value: -0.162 ; OR: 0.542 ), as compared to the enlisted men. Other significant data showed that older personnel had better health ( $\beta$-value: -0.0033 ; OR: 0.967$)$, and smokers accounted for more psychological morbidity in higher CHQ scores ( $\beta$-value: 0.377 ; OR: 1.458 ) (Table 3). VAS scores for self-reported health also revealed 
Table I Comparison of demographic factors, CHQ scores, and QOL scores by military rank (officer, NCO, enlisted men)

\begin{tabular}{|c|c|c|c|c|c|}
\hline & $\begin{array}{l}\text { Officer } \\
\text { Number (\%) } \\
\text { or mean } \pm \text { SD }\end{array}$ & $\begin{array}{l}\text { NCO } \\
\text { Number (\%) } \\
\text { or mean } \pm \text { SD }\end{array}$ & $\begin{array}{l}\text { Enlisted men } \\
\text { Number (\%) } \\
\text { or mean } \pm \text { SD }\end{array}$ & $P$-value & $\begin{array}{l}\text { Scheffe } \\
\text { post hoc }\end{array}$ \\
\hline \multicolumn{6}{|l|}{ Sex } \\
\hline Male & | 46 (9|.3) & $97(93.3)$ & $248(100)$ & $<0.001 *$ & $A, C$ \\
\hline Female & $14(8.8)$ & $7(6.7)$ & $0(0)$ & & \\
\hline Age (years) & $30.0 \pm 6.2$ & $25.3 \pm 3.9$ & $23.7 \pm 2.75$ & $<0.00 I^{*}$ & $A, B, C$ \\
\hline \multicolumn{6}{|l|}{ Military service } \\
\hline Army & |2| (79.6) & $48(46.6)$ & II 2 (48.3) & $<0.00 I^{*}$ & $A, B$ \\
\hline Air force & $7(4.6)$ & I (I.0) & $5(2.2)$ & & \\
\hline Gendarme & $24(15.8)$ & $54(52.4)$ & $115(49.6)$ & & \\
\hline \multicolumn{6}{|l|}{ Service type } \\
\hline Volunteer & I45 (95.4) & $50(49)$ & $13(5.7)$ & $<0.001 *$ & $A, B, C$ \\
\hline Mandatory & $7(4.6)$ & $52(5 \mathrm{I})$ & $215(94.3)$ & & \\
\hline Education (years) & $15.2 \pm 2.9$ & $14.3 \pm 3.0$ & $14.1 \pm 3.2$ & $0.04 *$ & $A$ \\
\hline Service years & II.I \pm 7.3 & $4.8 \pm 5.7$ & $1.5 \pm 2.4$ & $<0.001 *$ & $A, B, C$ \\
\hline \multicolumn{6}{|l|}{ Smoking history } \\
\hline Yes & $54(34.8)$ & 39 (37.9) & $84(35)$ & 0.858 & \\
\hline No & $101(65.2)$ & $64(62.1)$ & $156(65)$ & & \\
\hline \multicolumn{6}{|l|}{ Alcohol use } \\
\hline Yes & $13(8.2)$ & $13(13)$ & $25(10.5)$ & 0.465 & \\
\hline No & I45 (9I.8) & $87(87)$ & $212(89.5)$ & & \\
\hline \multicolumn{6}{|l|}{ VAS } \\
\hline Now & $72.5 \pm 13.1$ & $67.7 \pm 13.6$ & $66.3 \pm 14.1$ & $<0.00 I^{*}$ & $A, B$ \\
\hline Before service & $74.6 \pm 12.6$ & $71.0 \pm 16.8$ & $72.0 \pm 13.7$ & 0.079 & \\
\hline Total CHQ score & $9.62 \pm 5.61$ & II. $.07 \pm 5.48$ & $\mid 1.51 \pm 5.96$ & $0.005^{*}$ & A \\
\hline \multicolumn{6}{|l|}{ Cut-off point 9} \\
\hline$\leq 9$ & $93(57.4)$ & $40(38.5)$ & $106(42.2)$ & $0.002 *$ & $A, B$ \\
\hline$\geq 10$ & $69(42.6)$ & $64(61.5)$ & 145 (57.8) & & \\
\hline QOL score & $83.98 \pm 12.2$ & $80.64 \pm 10.8$ & $79.67 \pm I I .1$ & $0.001 *$ & \\
\hline Physical & $12.16 \pm 1.9$ & $11.46 \pm 1.8$ & $11.23 \pm 1.8$ & $<0.001 *$ & $A, B$ \\
\hline Psychological & $13.16 \pm 1.9$ & $12.98 \pm 1.8$ & $12.56 \pm 2.1$ & $0.009 *$ & B \\
\hline Social & $13.89 \pm 2.3$ & $13.28 \pm 2.4$ & $13.09 \pm 2.3$ & $0.003 *$ & B \\
\hline Environmental & $12.96 \pm 2.3$ & $12.26 \pm 2.1$ & $12.23 \pm 2.2$ & $0.009 *$ & $A, B$ \\
\hline
\end{tabular}

Notes: A: Statistically significant comparison of officers and enlisted men. B: Statistically significant comparison of officers and NCOs. C: Statistically significant comparison of NCOs and enlisted men. *Statistically significant difference.

Abbreviations: CHQ, General Health Questionnaire-12, Chinese version; QOL, quality of life; NCO, noncommissioned officer; SD, standard deviation;VAS, Visual Analog Scale.

significant differences between the CHQ cases and the non-CHQ cases. The participants experiencing one or more physical symptoms accounted for more CHQ cases ( $\beta$-value: 1.196; OR: 27.609).

The social and environmental domains on the QOL were significantly associated with lower CHQ case rates ( $\beta$-values: -0.133 and -0.287 ; ORs: 6.944 and 25.905 ) (Table 3).

For relationships between the QOL domains, VAS scores of self-reported health, and CHQ scores, we adjusted all the risk factors. As shown in Table 4, only military rank and ongoing physical illness showed a significant relationship.

\section{Discussion}

In this cross-sectional study, the QOL and CHQ scores, and their interactions, were analyzed in different military branches, ranks, and service types (voluntary or obligatory enlisted personnel). A total of $55.3 \%$ of all these subjects reported themselves as being unhealthy on the CHQ; this was higher than in the general population, as rates of $18 \%-33 \%$ were reported in different samples. ${ }^{30-34}$ Among our subjects, the NCOs and enlisted men rated themselves as having poor health $(61.5 \%$ and $57.8 \%$, respectively). This result was similar to that of a previous report in the UK. ${ }^{35}$

In previous studies, for military personnel either in training, combat, or peacekeeping missions, the GHQ case rates were $19.5 \%-48 \%$, higher than those found in studies of general populations. ${ }^{36-40}$ In one previous study performed in a military hospital, ${ }^{41}$ the GHQ case rates were $22 \%-32 \%$ for physicians, nurses, and other staff. This difference may reflect the different tools used and the different nature of 

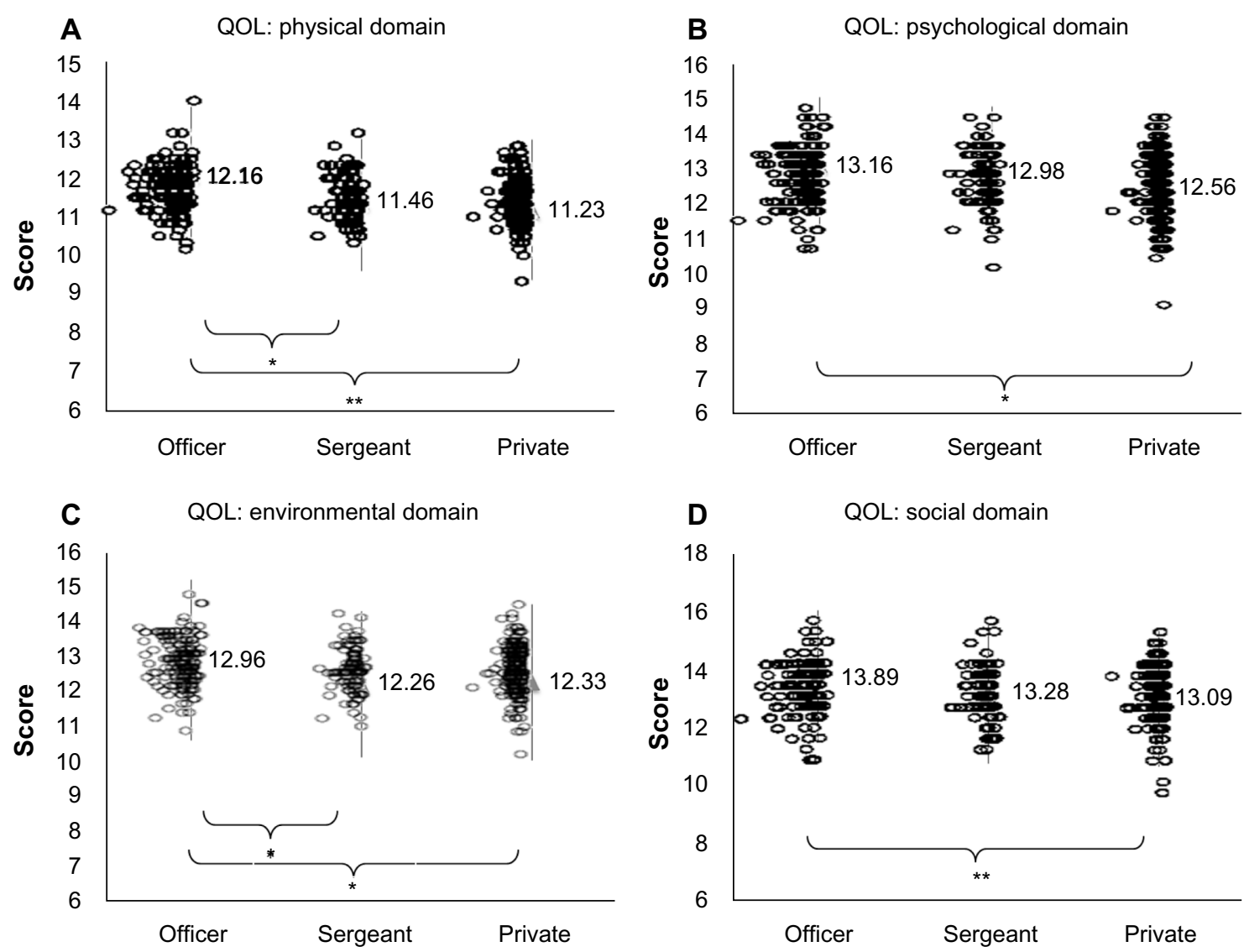

Figure I Comparison of the WHOQOL-BREF domain scores by rank.

Notes: QOL: physical domain (A); psychological domain (B); environmental domain (C); social domain (D). $* P<0.05$; $* * P<0.0$ I.

Abbreviations: QOL, quality of life; WHOQOL-BREF, World Health Organization Quality of Life Instrument, brief version.

stress for people who work for the hospital and for troops. In the present study, $55.3 \%$ of all the military subjects were CHQ cases; this rate was higher than the rates found in the militaries of other countries, and higher than that in our general population, or that found in other professions..$^{33,41}$
Among the different ranks, the CHQ case rate was $61 \%$ for NCOs, and this rate was higher than that of the other two groups. The CHQ case rate for obligatory service members was $58.9 \%$, and this was higher than that for volunteers $(48.9 \%)$.

Table $2 \mathrm{CHQ}$ item scores: comparison by rank (officer, NCO, enlisted men)

\begin{tabular}{|c|c|c|c|c|c|c|}
\hline & \multirow{2}{*}{$\frac{\text { Officer }}{\text { Mean } \pm \text { SD }}$} & \multirow{2}{*}{$\frac{\text { NCO }}{\text { Mean } \pm \text { SD }}$} & \multirow{2}{*}{$\frac{\text { Enlisted men }}{\text { Mean } \pm \text { SD }}$} & \multirow[t]{2}{*}{$\boldsymbol{F}$} & \multirow[t]{2}{*}{$P$-value } & \multirow{2}{*}{$\begin{array}{l}\text { Scheffe } \\
\text { post hoc }\end{array}$} \\
\hline & & & & & & \\
\hline I. Been suffering from headaches or pressure in your head & $1.72 \pm 0.90$ & $2.06 \pm 0.80$ & $1.93 \pm 0.87$ & 5.28 & $0.005^{*}$ & A \\
\hline 2. Had palpitations and worried that you might have heart trouble & $1.54 \pm 0.72$ & $1.52 \pm 0.75$ & $\mathrm{I} .6 \mathrm{I} \pm 0.76$ & 0.75 & 0.472 & \\
\hline 3. Had discomfort or a feeling of pressure in your chest & $1.50 \pm 0.69$ & $1.68 \pm 0.85$ & $1.69 \pm 0.81$ & 3.25 & $0.039 *$ & \\
\hline 4. Been suffering from shaking or numbness of your limbs & $1.43 \pm 0.62$ & $1.59 \pm 0.77$ & $1.62 \pm 0.80$ & 3.41 & $0.034^{*}$ & B \\
\hline 5. Lost much sleep through worry & $2.04 \pm 0.93$ & $2.52 \pm 0.95$ & $2.48 \pm 0.95$ & 13.08 & $<0.00 I^{*}$ & $A, B$ \\
\hline 6. Been taking things hard & $2.04 \pm 0.88$ & $2.25 \pm 0.79$ & $2.16 \pm 0.85$ & 2.16 & 0.116 & \\
\hline 7. Been getting along well with your family or friends & $2.38 \pm 0.90$ & $2.38 \pm 0.83$ & $2.49 \pm 0.90$ & 0.99 & 0.369 & \\
\hline 8. Been losing confidence in yourself & $\mathrm{I} .70 \pm 0.78$ & $1.75 \pm 0.77$ & $\mathrm{I} .83 \pm 0.83$ & 1.34 & 0.260 & \\
\hline 9. Been feeling nervous and strung-up all the time & $1.6 \mathrm{I} \pm 0.72$ & $1.80 \pm 0.79$ & $1.80 \pm 0.85$ & 3.08 & $0.047^{*}$ & \\
\hline 10. Been feeling hopeful about your future & $2.27 \pm 0.87$ & $2.73 \pm 0.79$ & $2.35 \pm 0.88$ & 2.42 & 0.900 & \\
\hline II. Been worried about your family or close friends & $1.85 \pm 0.78$ & $1.94 \pm 0.79$ & $1.92 \pm 0.83$ & 0.53 & 0.587 & \\
\hline 12. Felt that life is entirely hopeless & $1.55 \pm 0.72$ & $1.45 \pm 0.65$ & $\mathrm{I} .6 \mathrm{I} \pm 0.83$ & 1.59 & 0.206 & \\
\hline
\end{tabular}

Notes: A: Statistically significant comparison of officers and NCOs; B: Statistically significant comparison of officers and enlisted men. *Statistically significant difference. Abbreviations: CHQ, General Health Questionnaire-12, Chinese version; NCO, noncommissioned officer; SD, standard deviation. 
Table 3 Comparison of the demographic factors and WHOQOL domain scores by psychological morbidity

\begin{tabular}{|c|c|c|c|c|c|c|c|}
\hline & \multirow{2}{*}{$\begin{array}{l}\text { CHQ } \\
\text { score } \geq 10 \\
\text { Number } \\
\text { (\%) or } \\
\text { mean } \pm \text { SD }\end{array}$} & \multirow{2}{*}{$\begin{array}{l}\text { CHQ } \\
\text { score } \leq 9 \\
\text { Number } \\
\text { (\%) or } \\
\text { mean } \pm \text { SD }\end{array}$} & \multirow[t]{2}{*}{$\beta$} & \multirow[t]{2}{*}{$P$-value } & \multirow[t]{2}{*}{$\begin{array}{l}\text { Odds } \\
\text { ratio }\end{array}$} & \multicolumn{2}{|c|}{$\begin{array}{l}95 \% \mathrm{Cl} \text { for } \\
\text { experiment B }\end{array}$} \\
\hline & & & & & & Lower & Upper \\
\hline \multicolumn{8}{|l|}{ Rank } \\
\hline Officer & $69(42.6)$ & $93(57.4)$ & -0.612 & $0.003 *$ & 0.542 & 0.364 & 0.809 \\
\hline NCO & $64(6 \mid .5)$ & $40(38.5)$ & 0.157 & 0.511 & 1.170 & 0.733 & 1.867 \\
\hline Enlisted & I 45 (57.8) & $106(42.2)$ & & & & & \\
\hline \multicolumn{8}{|l|}{ Service } \\
\hline Army & I 55 (52.2) & I 42 (47.8) & -0.004 & 0.983 & 0.001 & 0.695 & 1.429 \\
\hline Air force & $39(66.1)$ & $20(33.9)$ & 0.576 & 0.063 & $3.46 I$ & 0.970 & 3.266 \\
\hline Gendarme & $103(52.3)$ & 94 (47.7) & & & & & \\
\hline \multicolumn{8}{|l|}{ Service type } \\
\hline Volunteer & 129 (48.9) & I 35 (5I.I) & -0.389 & $0.024 *$ & 5.090 & 0.483 & 0.950 \\
\hline Mandatory & $165(58.5)$ & II (4I.5) & & & & & \\
\hline \multicolumn{8}{|l|}{ Sex } \\
\hline Male & $378(56.2)$ & $295(43.8)$ & 0.322 & 0.412 & 1.38 & 0.639 & 2.981 \\
\hline Female & $13(48.1)$ & 14 (5I.9) & & & & & \\
\hline Age & $24.86 \pm 5.0$ & $25.68 \pm 4.8$ & -0.033 & $0.035^{*}$ & 0.967 & 0.938 & 0.998 \\
\hline Education (years) & $13.87 \pm 3.5$ & $14.14 \pm 3.2$ & -0.023 & 0.317 & 0.977 & 0.934 & 1.022 \\
\hline Income (NT, K) & $21.3 \pm 23.6$ & $22.5 \pm 26.4$ & 0.020 & 0.517 & 0.420 & 0.961 & 1.082 \\
\hline Physical illness & $29(22.8)$ & 98 (77.2) & 1.196 & $<0.00 I^{*}$ & 27.609 & 2.117 & 5.168 \\
\hline Alcohol use & $379(55.6)$ & 303 (44.4) & -0.117 & 0.059 & 3.573 & 0.788 & 1.004 \\
\hline Smoking & $90(38.5)$ & I 44 (6I.5) & 0.377 & $0.022 *$ & 1.458 & 1.057 & 2.011 \\
\hline VAS score (now) & $64.09 \pm 14.43$ & $73.43 \pm 11.11$ & -0.061 & $<0.00 I^{*}$ & 72.023 & 0.928 & 0.954 \\
\hline \multicolumn{8}{|l|}{ QOL } \\
\hline Physical & II. $.04 \pm 1.87$ & $12.04 \pm 1.84$ & -0.035 & 0.539 & 0.377 & 0.863 & 1.080 \\
\hline Psychological & $12.24 \pm 2.05$ & $13.28 \pm 1.90$ & 0.013 & 0.814 & 0.055 & 0.907 & 1.132 \\
\hline Social & $12.58 \pm 2.42$ & $14.06 \pm 2.09$ & -0.133 & $0.008^{*}$ & 6.944 & 0.793 & 0.967 \\
\hline Environmental & $11.62 \pm 2.26$ & $13.30 \pm 1.97$ & -0.287 & $<0.001^{*}$ & 25.905 & 0.672 & 0.838 \\
\hline
\end{tabular}

Note: *Statistically significant difference.

Abbreviations: WHOQOL, World Health Organization Quality of Life Instrument; CHQ, General Health Questionnaire-I2, Chinese version; N, number; CI, confidence interval; NCO, noncommissioned officer; NT, New Taiwan dollars; K, thousands; VAS, Visual Analog Scale; QOL, quality of life.

In Table 5, we have reviewed several previously selected studies conducted among different military and nonmilitary populations. In mobilized military personnel, the nature of military stress, rather than age or other demographic data (for example, combat-related deployments, peacekeeping or disaster relief actions, or outbreaks of infectious diseases), ${ }^{35,41-47}$ is most likely to be related to psychological morbidity and poor quality of life. In the peace time contrarily ${ }^{41}$ and among the general population, ${ }^{48,49}$ age may play a role in contributing to psychological morbidity and poor QOL in one study that was conducted from a military hospital, in two other studies conducted in the general population. ${ }^{41}$ In previous studies conducted among students, ${ }^{50-52}$ which had a similar age distribution as that of the present study, the GHQ rates varied from $29 \%-52 \%$ and were higher in the female sex, among subjects experiencing stressful events, those with a basic level of training, those with academic problems, and family social economic status. However, these studies, including the present one, varied greatly in the number of participants, other demographic data, countries, and stress nature in the target population. Furthermore, the present study is a cross-sectional study; the associations between the demographic factors and psychological morbidity or QOL are hard to compare with other studies.

Some research has shown that the GHQ was better at screening for minor psychiatric morbidity such as depression. ${ }^{53,54}$ In the military, psychological factors, as well as social and environmental problems could be risk factors for suicidal ideations. ${ }^{55}$ Higher case rates require more attention.

In a previous study, ${ }^{56}$ age may have been an independent risk factor for poor psychological health; however, in the present study, age was slightly negatively related to CHQ scores and, after adjustment by multiple regression analysis for rank, the influence of age on CHQ disappeared. The reason may be that those with higher ranks in the military are often older than 
Table 4 Multiple regression analysis of factors for $\mathrm{CHQ}$, QOL, and VAS of health

\begin{tabular}{|c|c|c|c|c|c|}
\hline & \multirow[t]{2}{*}{$\begin{array}{l}\text { Regression } \\
\text { coefficient }\end{array}$} & \multirow[t]{2}{*}{ SE } & \multicolumn{2}{|c|}{$\begin{array}{l}95 \% \mathrm{Cl} \text { for } \\
\text { regression } \\
\text { coefficient }\end{array}$} & \multirow[t]{2}{*}{$P$-value } \\
\hline & & & Lower & Upper & \\
\hline \multicolumn{6}{|l|}{ Total CHQ score } \\
\hline Constant & 14.78 & 2.37 & 10.121 & 19.440 & $<0.001$ \\
\hline Rank & -0.87 & 0.38 & -1.621 & -0.111 & $0.025 *$ \\
\hline Age & -0.09 & 0.10 & -0.295 & 0.112 & 0.376 \\
\hline Sex & -0.51 & 0.46 & -1.422 & 0.394 & 0.266 \\
\hline Education & -0.04 & 0.09 & -0.214 & 0.140 & 0.678 \\
\hline Service & -0.09 & 0.07 & -0.229 & 0.047 & 0.196 \\
\hline Years of service & 0.09 & 0.08 & -0.080 & 0.256 & 0.303 \\
\hline Income & 0.03 & 0.10 & -0.173 & 0.235 & 0.767 \\
\hline Physical illness & 3.42 & 0.62 & 2.199 & 4.639 & $<0.00 I^{*}$ \\
\hline \multicolumn{6}{|l|}{ Total QOL score } \\
\hline Constant & 71.81 & 4.73 & 62.52 & 81.10 & $<0.001$ \\
\hline Rank & 1.52 & 0.76 & 0.018 & 3.028 & $0.045^{*}$ \\
\hline Age & 0.30 & 0.20 & -0.103 & 0.708 & 0.144 \\
\hline Sex & 0.55 & 0.92 & -1.260 & 2.360 & 0.551 \\
\hline Education & -0.01 & 0.18 & -0.362 & 0.343 & 0.958 \\
\hline Service & 0.01 & 0.14 & -0.262 & 0.287 & 0.930 \\
\hline Years of service & -0.13 & 0.17 & -0.463 & 0.206 & 0.451 \\
\hline Income & -0.26 & 0.21 & -0.672 & 0.143 & 0.202 \\
\hline Physical illness & -2.39 & 1.23 & -4.824 & 0.038 & 0.054 \\
\hline \multicolumn{6}{|l|}{ VAS score (now) } \\
\hline Constant & 56.71 & 5.89 & 45.13 & 68.29 & $<0.001$ \\
\hline Rank & 1.95 & 0.96 & 0.071 & 3.824 & $0.040 *$ \\
\hline Age & 0.18 & 0.26 & -0.327 & 0.685 & 0.487 \\
\hline Sex & 1.69 & 1.15 & -0.560 & 3.953 & 0.140 \\
\hline Education (years) & 0.25 & 0.22 & -0.188 & 0.691 & 0.261 \\
\hline Service & -0.19 & 0.17 & -0.538 & 0.147 & 0.262 \\
\hline Years of service & -0.03 & 0.21 & -0.450 & 0.385 & 0.879 \\
\hline Income & 0.15 & 0.26 & -0.358 & 0.657 & 0.562 \\
\hline Physical illness & -5.86 & 1.54 & -8.897 & -2.836 & $<0.00 I^{*}$ \\
\hline
\end{tabular}

Notes: $R$-squared of total CHQ: $0.081 ; R$-squared of QOL: $0.038 ; R$-squared of VAS: 0.076 . *Statistically significant difference.

Abbreviations: $\mathrm{CHQ}$, General Health Questionnaire-12, Chinese version; QOL, quality of life; VAS, Visual Analog Scale; SE, standardized error; Cl, confidence interval.

NCOs and enlisted men; however, among enlisted men, age still played a role, as most of the subjects rating themselves as "healthy" were older than those not rating themselves as such $(\beta=-0.160 ; P=0.013)$. This may reflect the fact that even mandatory personnel who have spent more time in the service can better adapt to the military environment and life. On the other hand, younger soldiers, especially those who were subject to obligatory military enlistment, faced more challenges in adaptation than did the veterans. It is important to help these individuals adapt faster.

In previous studies, ${ }^{22,57}$ people with more education may have a greater ability to express their emotions, and they received higher scores on health questionnaires. In our data, however, the CHQ was inversely related to higher rank, which represents older age and greater levels of education. Those with lower levels of education may also have underestimated their health status.

The VAS of self-reported health - a subjective and overall scale for health status - was lower in NCOs and enlisted men and higher in officers. This suggested that officers with higher rank and more time spent in the military (an average of 13 years) had better subjective health. Although this was not specific to individual domains, this overall finding was similar to the results found for the CHQ.

The VAS showed a significant difference between CHQ cases and non-CHQ cases, with a disparity of up to 10 points. When multiple regression analysis was used to adjust the risk factors for VAS, rank and illness were independent risk factors. Previous studies revealed that VAS was a useful tool for quantifying QOL, ${ }^{58}$ and the VAS correlated with GHQ across specific diseases. ${ }^{59}$ The present study may suggest that VAS could be used as a quick screening tool for mental health, which is suitable for certain emergent stressful missions such as disaster rescue, although more studies are needed.

In the analysis of the subitems on the CHQ, NCOs had more headaches and sleep problems than did officers, and the enlisted men had more limb numbness and sleep problems than did officers. This may reflect the frequent shift work due to some security duty and heavy demands of military services loaded on the NCOs and enlisted persons. A focus on sleep hygiene and appropriate workload allocation is important. Further study of sleep in military personnel and its relation to mood and health status should be considered.

In each domain of QOL, officers had better scores than did enlisted men in terms of general QOL, physical symptoms (concentration, daily energy levels, physical pain, sleep), sex life, appearance, leisure activities, capacity for work, money, respect (a CHQ question), and food (a CHQ question). The WHOQOL scores may have a negative association with the presence and severity of psychopathology. ${ }^{60,61}$ In our research, we also found that military personnel who had lower social and environmental domain scores on the WHOQOL had higher CHQ case rates. This may indicate an area for future investigation and a way to improve the status of military personnel.

There are limitations to this study. First, there were very few female subjects, and the sex-related differences could not be studied well in such a military environment. Given that so many participants did not provide marital status data, it became more difficult to analyze this potential confounder. Second, our questionnaire distribution did not cover modern military diversity and specialization. Although our 
Table 5 Comparison of previous research on psychological morbidity in different military or nonmilitary populations

\begin{tabular}{|c|c|c|c|}
\hline Authors, publication year & Subjects in the study population & Finding & Case number \\
\hline Proctor et al, $2001^{42}$ & $\begin{array}{l}\text { Military (mobilized): US Gulf } \\
\text { War-deployed veterans }\end{array}$ & $\begin{array}{l}\text { Gulf War-deployed veterans report lower } \\
\text { functional health status }\end{array}$ & $14 \mid$ \\
\hline Richardson et al, $2008^{43}$ & $\begin{array}{l}\text { Military (mobilized): Canadian } \\
\text { peacekeeping veterans }\end{array}$ & $\begin{array}{l}\text { Veterans with PTSD have significant } \\
\text { impairments in mental and physical health- } \\
\text { related QOL }\end{array}$ & 125 \\
\hline Forman-Hoffman et al, $2005^{44}$ & $\begin{array}{l}\text { Military (mobilized): US Gulf } \\
\text { War-deployed veterans }\end{array}$ & $\begin{array}{l}\text { Two or more mental disorders associated } \\
\text { with impaired health-related } \mathrm{QOL}\end{array}$ & 602 \\
\hline Fear et al, $2009^{35}$ & $\begin{array}{l}\text { Military (mobilized): UK war-fighting } \\
\text { veterans }\end{array}$ & $\begin{array}{l}\text { Reported job strain and rank contributed } \\
\text { independently to psychological symptoms }\end{array}$ & 4,722 \\
\hline Kehle et al, $201 \mathrm{I}^{45}$ & $\begin{array}{l}\text { Military (mobilized): US National } \\
\text { Guard soldiers deployed to Iraq }\end{array}$ & $\begin{array}{l}\text { Mental health diagnoses associated with } \\
\text { poorer functioning and QOL; PTSD has the } \\
\text { strongest relationship with poor social } \\
\text { functioning and QOL }\end{array}$ & 348 \\
\hline Marimoutou et al, $2012^{46}$ & $\begin{array}{l}\text { Military (mobilized): French } \\
\text { gendarmes after chikungunya } \\
\text { infection: nonhealed, healed patients, } \\
\text { and uninfected subjects }\end{array}$ & $\begin{array}{l}\text { All dimensions of the physical and mental } \\
\text { components were impaired in chikungunya } \\
\text { infection nonhealed subjects }\end{array}$ & $\begin{array}{l}\text { Nonhealed: } 37 \\
\text { Healed: } 48 \\
\text { Uninfected: } 297\end{array}$ \\
\hline Tzeng et al, 200941 & $\begin{array}{l}\text { Military (peace time): Physicians, } \\
\text { nurses, other specialists in a military } \\
\text { hospital in South Taiwan }\end{array}$ & $\begin{array}{l}\text { Younger, hypnotic drug use, and life events } \\
\text { had a higher percentage in the psychological } \\
\text { morbidity group, and poor QOL }\end{array}$ & $\begin{array}{l}\text { Physicians: } 65 \\
\text { Nurses: } 416 \\
\text { Others: } 304\end{array}$ \\
\hline Kongsakon et al, $2012^{47}$ & $\begin{array}{l}\text { Military personnel and their families } \\
\text { (peace time): Navy and their spouses, } \\
6 \text { months after the } 2006 \text { tsunami }\end{array}$ & $\begin{array}{l}\text { Bodily pain, the only indicator subscale } \\
\text { of the QOL that was statistically significantly } \\
\text { associated with tsunami exposure }\end{array}$ & 434 \\
\hline Mirkovic et al, $2012^{48}$ & $\begin{array}{l}\text { Civilian, nonmilitary: Adult residents } \\
\text { of northern Kosovska Mitrovica }\end{array}$ & $\begin{array}{l}\text { Mental health problems were associated with } \\
\text { older age, poor financial situation, abuse }\end{array}$ & 130 \\
\hline Gu et al, $2009^{49}$ & $\begin{array}{l}\text { Civilian, nonmilitary: A multilevel cross- } \\
\text { sectional study of mental disorder in } \\
\text { community settings in Zhejiang Province }\end{array}$ & $\begin{array}{l}\text { The mental disorder was associated with } \\
\text { age, marital status, residency, education, } \\
\text { occupation, and household income. }\end{array}$ & 14,632 \\
\hline
\end{tabular}

Abbreviations: PTSD, posttraumatic stress disorder; QOL, quality of life.

questionnaire return rate was $60 \%$, there were many units that were unwilling to receive it. For example, we have few data about marines and navy personnel. We do plan to conduct further qualitative research in this area with sleep or depression instruments such as the Pittsburgh Sleep Quality Index ${ }^{62}$ and the Beck Depression Inventory ${ }^{63}$ to render the data more complete. Finally, this is a cross-sectional study; the relationship between demographic factors and QOL is hard to determine and needs further longitudinal studies. Some analyses could only be compared with those of previous studies, but not exactly under the same demographic data.

\section{Conclusion}

In addition to the combat readiness of our forces, disaster relief is now an important task. Our military personnel have statistically higher CHQ case rates than do members of the general population, and the average case rates of other countries' military personnel are lower than those noted in our study. Whether there is a higher risk for posttraumatic stress disorder or other mental illnesses when executing rescue or disaster missions is of serious concern. In addition, it is worth noting that rank is an independent factor that affects the mental health of military personnel and their QOL. We should pay more attention to our military personnel's mental health, as well as to their physical health. The VAS of self-reported health might be a useful tool for screening military mental health. It could be used in a war situation or during emergency mobilization, and it takes less time than administering a more comprehensive survey.

\section{Acknowledgments}

This article was funded by a grant from the Ministry of Health and Welfare, Taiwan as DOH94-TD-M-113-037.

The authors thank Ms Jessie Wei-Shan Chiang for her help in the paperwork and proofreading.

\section{Disclosure}

The authors report no conflicts of interest in this work.

\section{References}

1. Hourani LL, Williams TV, Kress AM. Stress, mental health, and job performance among active duty military personnel: findings from the 2002 Department of Defense Health-Related Behaviors Survey. Mil Med. 2006;171(9):849-856. 
2. Pflanz SE, Ogle AD. Job stress, depression, work performance, and perceptions of supervisors in military personnel. Mil Med. 2006;171(9): 861-865.

3. Kang HK, Hyams KC. Mental health care needs among recent war veterans. $N$ Engl J Med. 2005;352(13):1289.

4. Kang HK, Li B, Mahan CM, Eisen SA, Engel CC. Health of US veterans of 1991 Gulf War: a follow-up survey in 10 years. J Occup Environ Med. 2009;51(4):401-410.

5. Smith TC, Wingard DL, Ryan MA, Kritz-Silverstein D, Slymen DJ, Sallis JF; Millennium Cohort Study Team. PTSD prevalence, associated exposures, and functional health outcomes in a large, population-based military cohort. Public Health Rep. 2009;124(1):90-102.

6. Yan GW, McAndrew L, D’Andrea EA, et al. Self-reported stressors of National Guard women veterans before and after deployment: the relevance of interpersonal relationships. J Gen Intern Med. 2013 28 Suppl 2:S549-S555.

7. Olsen OK, Pallesen S, Espevik R. The impact of partial sleep deprivation on military naval officers' ability to anticipate moral and tactical problems in a simulated maritime combat operation. Int Marit Health 2013;64(2):61-65.

8. Luxton DD, Greenburg D, Ryan J, Niven A, Wheeler G, Mysliwiec V. Prevalence and impact of short sleep duration in redeployed OIF soldiers. Sleep. 2011;34(9):1189-1195.

9. Riggs SA, Riggs DS. Risk and resilience in military families experiencing deployment: the role of the family attachment network. J Fam Psychol. 2011;25(5):675-687.

10. Sareen J, Cox BJ, Afifi TO, et al. Combat and peacekeeping operations in relation to prevalence of mental disorders and perceived need for mental health care: findings from a large representative sample of military personnel. Arch Gen Psychiatry. 2007;64(7):843-852.

11. Davis BE, Blaschke GS, Stafford EM. Military children, families, and communities: supporting those who serve. Pediatrics. 2012;129 Suppl 1: S3-S10.

12. Verdeli H, Baily C, Vousoura E, Belser A, Singla D, Manos G. The case for treating depression in military spouses. J Fam Psychol. 2011;25(4): 488-496.

13. Richards KB, Bowen GL. Military downsizing and its potential implications for Hispanic, Black, and White soldiers. J Prim Prev. 1993;14(1):73-92.

14. Patel R. Testing an organizational commitment model in the context of a downsizing Russian military. Dissertation Abstracts International: Section B: The Sciences and Engineering. 2000;60(12-B): 6406.

15. van Eetveldt MW, van de Ven N, van den Tooren M, Versteeg RC. The Importance of Career Insecurity for Turnover Intentions in the Dutch Military. Milit Psychol. 2013;25(5):489-501.

16. Cheng TA, Wu JT, Chong MY, Williams P. Internal consistency and factor structure of the Chinese Health Questionnaire. Acta Psychiatr Scand. 1990;82(4):304-308

17. Larson JS. The conceptualization of health. Med Care Res Rev. 1999;56(2):123-136.

18. The World Health Organization Quality of Life assessment (WHOQOL): position paper from the World Health Organization. Soc Sci Med. 1995;41(10):1403-1409.

19. Orley J, Saxena S, Herrman H. Quality of life and mental illness. Reflections from the perspective of the WHOQOL. Br J Psychiatry. 1998;172:291-293.

20. Martins LC, Lopes CS. Military hierarchy, job stress, and mental health in peace time. Occup Med(Lond). 2012;62(3):182-187.

21. Goldberg DP, Hillier VF. A scaled version of the General Health Questionnaire. Psychol Med. 1979;9(1):139-145.

22. Chong MY, Wilkinson G. Validation of 30- and 12-item versions of the Chinese Health Questionnaire (CHQ) in patients admitted for general health screening. Psychol Med. 1989;19(2):495-505.

23. Chen CS, Tsang HY, Chong MY, Tang TC. Validation of the Chinese Health Questionnaire (CHQ-12) in community elders. Kaohsiung J Med Sci. 2000;16(11):559-565.
24. Yao G, Chung CW, Yu CF, Wang JD. Development and verification of validity and reliability of the WHOQOL-BREF Taiwan version. J Formos Med Assoc. 2002;101(5):342-351.

25. Cheng TA, Williams P. The design and development of a screening questionnaire (CHQ) for use in community studies of mental disorders in Taiwan. Psychol Med. 1986;16(2):415-422.

26. Ostile IL, Johansson I, Aasland A, Flatö B, Möller A. Self-rated physical and psychosocial health in a cohort of young adults with juvenile idiopathic arthritis. Scand J Rheumatol. 2010;39(4):318-325.

27. Zub LW, Szymczyk M, Pokryszko-Dragan A, Bilinńska M. Evaluation of pain in patients with lumbar disc surgery using VAS scale and quantitative sensory testing. Adv Clin Exp Med. 2013;22(3):411-419.

28. Akakura K, Matsuzaki K, Kobayashi T, et al. [Evaluation of utility index of quality of life (QOL) in prostate cancer patients: comparison of QOL utility index EuroQol-5D (EQ-5D) and visual analogue scale (VAS) with health-related QOL questionnaires SF-36 and EPIC]. Nihon Hinyokika Gakkai Zasshi. 2011;102(1):9-13. Japanese.

29. Rashidi AA, Anis Ah, Marra CA. Do visual analogue scale (VAS) derived standard gamble (SG) utilities agree with Health Utilities Index utilities? A comparison of patient and community preferences for health status in rheumatoid arthritis patients. Health Qual Life Outcomes. 2006;4:25.

30. Cheng TA. A community study of minor psychiatric morbidity in Taiwan. Psychol Med. 1988;18(4):953-968.

31. Lahelma E, Martikainen P, Rahkonen O, Roos E, Saastamoinen P. Occupational class inequalities across key domains of health: results from the Helsinki Health Study. Eur J Public Health. 2005;15(5): 504-510.

32. Niedhammer I, Chastang JF, David S, Barouhiel L, Barrandon G. Psychosocial work environment and mental health: Job-strain and effort-reward imbalance models in a context of major organizational changes. Int J Occup Environ Health. 2006;12(2):111-119.

33. Cheng TA. A pilot study of mental disorders in Taiwan. Psychol Med. 1985;15(1):195-203.

34. Yang TZ, Huang L, Wu ZY. [The application of Chinese health questionnaire for mental disorder screening in community settings in mainland China]. Zhonghua Liu Xing Bing Xue Za Zhi. 2003;24(9):769-773. Chinese.

35. Fear NT, Rubin GJ, Hatch S, et al. Job strain, rank, and mental health in the UK Armed Forces. Int J Occup Environ Health. 2009;15(3): 291-298.

36. Martins LC, Kuhn L. [Prevalence of common mental disorders in recently-drafted young Brazilians to mandatory military service and associated factors]. Cien Saude Colet. 2013;18(6):1809-1816. Portuguese.

37. Mulligan K, Jones N, Woodhead C, Davies M, Wessely S, Greenberg N Mental health of UK military personnel while on deployment in Iraq Br J Psychiatry. 2010;197(5):405-410.

38. Argyropoulos IT, Samakouri MA, Balascas DK, Dalapascha M, Pallas DP, Livaditis MD. Mental health problems of Army personnel seen in medical outpatient clinics in Greece. Int $J$ Psychiatry Med. 2005;35(3):225-239.

39. Ward W. Psychiatric morbidity in Australian veterans of the United Nations peacekeeping force in Somalia. Aust $N$ Z J Psychiatry. 1997;31(2):184-193.

40. Schei E. A strengthening experience? Mental distress during military service. A study of Norwegian army conscripts. Soc Psychiatry Psychiatr Epidemiol. 1994;29(1):40-45.

41. Tzeng DS, Chung WC, Fan PL, Lung FW, Yang CY. Psychological morbidity, quality of life and their correlations among military health care workers in Taiwan. Ind Health. 2009;47(6):626-634.

42. Proctor SP, Harley R, Wolfe J, Heeren T, White RF. Health-related quality of life in Persian Gulf War Veterans. Mil Med. 2001;166(6): 510-519.

43. Richardson JD, Long ME, Pedlar D, Elhai JD. Posttraumatic stress disorder and health-related quality of life among a sample of treatmentand pension-seeking deployed Canadian Forces peacekeeping veterans. Can J Psychiatry. 2008;53(9):594-600. 
44. Forman-Hoffman VL, Carney CP, Sampson TR, et al. Mental health comorbidity patterns and impact on quality of life among veterans serving during the first Gulf War. Qual Life Res. 2005;14(10): 2303-2314.

45. Kehle SM, Reddy MK, Ferrier-Auerbach AG, Erbes CR, Arbisi PA, Polusny MA. Psychiatric diagnoses, comorbidity, and functioning in National Guard troops deployed to Iraq. J Psychiatr Res. 2011;45(1): 126-132.

46. Marimoutou C, Vivier E, Oliver M, Boutin JP, Simon F. Morbidity and impaired quality of life 30 months after chikungunya infection: comparative cohort of infected and uninfected French military policemen in Reunion Island. Medicine (Baltimore). 2012;91(4):212-219.

47. Kongsakon R, Putthavarang T, Thomyangkoon P. Quality of life among the navies and their spouses survivors, six months after the tsunami disaster in Phang-Nga Naval Base, Thailand. J Med Assoc Thai. 2012;95(5):716-722.

48. Mirković M, Simić S, Trajković G. Assessment of mental health in adults of the northern part of the city of Kosovska Mitrovica. Vojnosanit Pregl. 2012;69(9):747-752.

49. Gu YM, Xu FZ, Shi QC, Yang TZ, Li L. [A multilevel cross-sectional study of mental disorder in community settings in Zhejiang Province]. Zhonghua Yu Fang Yi Xue Za Zhi. 2009;43(12):1105-1108. Chinese.

50. Jafari N, Loghmani A, Mantazeri A. Mental health of medical students in different levels of training. Int J Prev Med. 2012;3(Suppl 1): S107-S112.

51. Uras C, Gennaro R, Aparo UL, Tabolli S. [Risk of anxiety and depression in nursing students in Rome (Italy)]. Ig Sanita Pubbl. 2012;68(4): 555-564. Italian.

52. Yusoff MS, Abdul Rahim AF, Yaacob MJ. Prevalence and sources of stress among Universiti Sains Malaysia medical students. Malays J Med Sci. 2010;17(1):30-37.

53. Romppel M, Braehler E, Roth M, Glaesmer H. What is the General Health Questionnaire-12 assessing? Dimensionality and psychometric properties of the General Health Questionnaire-12 in a large scale German population sample. Compr Psychiatry. 2013;54(4):406-413.
54. Aalto AM, Elovainio M, Kivimäki M, Uutela A, Pirkola S. The Beck Depression Inventory and General Health Questionnaire as measures of depression in the general population: a validation study using the Composite International Diagnostic Interview as the gold standard. Psychiatry Res. 2012;197(1-2):163-171.

55. Anisi J, Majdian M, Mirzamani SM. The factors associated with suicide ideation in Iranian soldiers. Iran J Psychiatry. 2010;5(3):97-101.

56. Jones M, Rona RJ, Hooper R, Wesseley S. The burden of psychological symptoms in UK Armed Forces. Occup Med (Lond). 2006;56(5): 322-328.

57. McManus IC, Winder BC, Gordon D. The causal links between stress and burnout in a longitudinal study of UK doctors. Lancet. 2002;359(9323):2089-2090.

58. Sasaki R, Habuchi T, Osamu O, et al. [The quality of life after radical prostatectomy measured by general health questionnaire and visual analogue scales]. Nihon Hinyokika Gakkai Zasshi. 2000;91(1):21-28. Japanese.

59. Hansen NC, Skriver A, Brorsen-Riis L, et al. Orally administered $\mathrm{N}$-acetylcysteine may improve general well-being in patients with mild chronic bronchitis. Respir Med. 1994;88(7):531-535.

60. Masthoff ED, Trompenaars FJ, Van Heck GL, Hodiamont PP, De Vries J. Quality of life and psychopathology: investigations into their relationship. Aust N Z J Psychiatry. 2006;40(4):333-340.

61. Huang IC, Wu AW, Frangakis C. Do the SF-36 and WHOQOL-BREF measure the same constructs? Evidence from the Taiwan population*. Qual Life Res. 2006;15(1):15-24.

62. Buysse DJ, Reynolds CF, 3rd, Monk TH, Berman SR, Kupfer DJ. The Pittsburgh Sleep Quality Index: A new instrument for psychiatric practice and research. Psychiatry Research. 1989;28(2):193-213.

63. Beck AT, Beamesderfer A. Assessment of depression: The depression inventory. Modern Problems of Pharmacopsychiatry. $1974 ; 7: 151-169$.
Neuropsychiatric Disease and Treatment

\section{Publish your work in this journal}

Neuropsychiatric Disease and Treatment is an international, peerreviewed journal of clinical therapeutics and pharmacology focusing on concise rapid reporting of clinical or pre-clinical studies on a range of neuropsychiatric and neurological disorders. This journal is indexed on PubMed Central, the 'PsycINFO' database and CAS.

\section{Dovepress}

The manuscript management system is completely online and includes a very quick and fair peer-review system, which is all easy to use. Visit http://www.dovepress.com/testimonials.php to read real quotes from published authors. 